\title{
Dual Perspectives
}

Dual Perspectives Companion Paper: Evidence for Adult Hippocampal Neurogenesis in Humans, by Elena MorenoJiménez et al.

\section{Positive Controls in Adults and Children Support That Very Few, If Any, New Neurons Are Born in the Adult Human Hippocampus}

\author{
${ }^{\oplus}$ Shawn F. Sorrells, ${ }^{1 *}$ Mercedes F. Paredes, ${ }^{2 *}{ }^{\circledR}$ Zhuangzhi Zhang, ${ }^{3}$ Gugene Kang, ${ }^{7}$ Oier Pastor-Alonso, ${ }^{2}$ \\ ${ }^{\circledR}$ Sean Biagiotti, ${ }^{1}{ }^{\circledR}$ Chloe E. Page, ${ }^{1}$ Kadellyn Sandoval, ${ }^{2}{ }^{\circledR}$ Anthony Knox, ${ }^{4}$ Andrew Connolly, ${ }^{4}{ }^{\circledR}$ Eric J. Huang, ${ }^{4}$ \\ Jose Manuel Garcia-Verdugo, ${ }^{5}$ Michael C. Oldham, ${ }^{7}{ }^{1}$ Zhengang Yang, $^{3}$ and Arturo Alvarez-Buylla ${ }^{6,7}$ \\ ${ }^{1}$ Department of Neuroscience, University of Pittsburgh, Pittsburgh, Pennsylvania 15260, ${ }^{2}$ Department of Neurology, University of California San \\ Francisco, San Francisco, California 94143, ${ }^{3}$ State Key Laboratory of Medical Neurobiology and Institutes of Brain Science, Fudan University, \\ Shanghai, P.R. 200032 China, ${ }^{4}$ Department of Pathology, University of California San Francisco, San Francisco, California 94143, ${ }^{5}$ Laboratorio de \\ Neurobiología Comparada, Instituto Cavanilles, Universidad de Valencia, Centro de Investigación Biomédica en Red de Enfermedades \\ Neurodegenerativas, Valencia 46980, Spain, ${ }^{6}$ Eli and Edythe Broad Center of Regeneration Medicine and Stem Cell Research, University of \\ California San Francisco, San Francisco, California 94143, and ${ }^{7}$ Department of Neurological Surgery, University of California San Francisco, San \\ Francisco, California 94143
}

Adult hippocampal neurogenesis was originally discovered in rodents. Subsequent studies identified the adult neural stem cells and found important links between adult neurogenesis and plasticity, behavior, and disease. However, whether new neurons are produced in the human dentate gyrus (DG) during healthy aging is still debated. We and others readily observe proliferating neural progenitors in the infant hippocampus near immature cells expressing doublecortin (DCX), but the number of such cells decreases in children and few, if any, are present in adults. Recent investigations using dual antigen retrieval find many cells stained by DCX antibodies in adult human DG. This has been interpreted as evidence for high rates of adult neurogenesis, even at older ages. However, most of these DCX-labeled cells have mature morphology. Furthermore, studies in the adult human DG have not found a germinal region containing dividing progenitor cells. In this Dual Perspectives article, we show that dual antigen retrieval is not required for the detection of DCX in multiple human brain regions of infants or adults. We review prior studies and present new data showing that DCX is not uniquely expressed by newly born neurons: DCX is present in adult amygdala, entorhinal and parahippocampal cortex neurons despite being absent in the neighboring DG. Analysis of available RNA-sequencing datasets supports the view that DG neurogenesis is rare or absent in the adult human brain. To resolve the conflicting interpretations in humans, it is necessary to identify and visualize dividing neuronal precursors or develop new methods to evaluate the age of a neuron at the single-cell level.

Key words: aging; dentate gyrus; doublecortin; human hippocampus; new neurons; neural progenitors; neurogenesis

Introduction

Two regions of the rodent brain continue generating new neurons into adulthood: the dentate gyrus (DG) of the hippocampus

Received May 26, 2020; revised Nov. 6, 2020; accepted Nov. 10, 2020

Author contributions: S.F.S., M.F.P., Z.Y., and A.A.-B. designed research; S.F.S., M.F.P., S.B., K.S., and Z.Z. performed research; S.F.S., M.F.P., O.P.-A., C.E.P., A.K., G.K., M.C.O., Z.Y., and A.A.-B. analyzed data; S.F.S., M.F.P., and A.A.-B wrote the first draft of the paper; S.F.S., M.F.P., A.A.-B, A.C., J.M.G.-V., and E.J.-H revised and edited the paper.

This work was supported by National Institute of Neurological Disorders and Stroke K08 NS091537 to M.F.P., Roberta and Oscar Gregory Endowment in Stroke and Brain Research to M.F.P., and National Institute of Mental Health R01MH123156 and R01MH113896 to M.C.0. and G.K. The Genotype-Tissue Expression (GTEx) Project was supported by the Common Fund of the Office of the Director of the National Institutes of Health, and by National Cancer Institute, National Human Genome Research Institute, National Heart, Lung, and Blood Institute, National Institute on Drug Abuse, National Institute of Mental Health, and National Institute of Neurological Disorders and Stroke. Tissue collection was performed with previous patient consent in strict
(Altman and Das, 1965; Kornack and Rakic, 1999; Seri et al., 2001; van Praag et al., 2002) and the ventricular-subventricular zone (V-SVZ) along the walls of the lateral ventricles, which

observance of the legal and institutional ethical regulations of each participating institution and was supported by grants from the National Institutes of Health (P01NS083513) to the University of California, San Francisco and and the generous donation by families to University of California, San Francisco, Shangai Medical College, the Hospital La Fe and the University of Valencia. We thank Vicente Herranz-Pérez, Trevor Sorrells, and Alice Paredes for comments and edits.

*S.F.S. and M.F.P. contributed equally to this work.

The authors declare no competing financial interests.

Correspondence should be addressed to Arturo Alvarez-Buylla at AlvarezBuyllaA@ucsf.edu.

https://doi.org/10.1523/JNEUROSCI.0676-20.2020

Copyright $\odot 2021$ the authors 
Table 1. Markers frequently used to study adult neurogenesis and their limitations

\begin{tabular}{|c|c|c|c|}
\hline$\overline{\text { Marker }}$ & Common use & Limitations to marker interpretation & References \\
\hline Ki-67 & Cell proliferation & $\begin{array}{l}\text { Includes dividing cells of non-neuronal lineage; also expressed } \\
\text { in postmitotic neurons for DNA repair }\end{array}$ & $\begin{array}{l}\text { Namba et al., 2005; Schwartz et al., 2007; Munakata et al., } \\
\text { 2013; Boldrini et al., } 2018\end{array}$ \\
\hline MCM2 & Cell proliferation & $\begin{array}{l}\text { Can be expressed on cell cycle reentry occasionally prior to cell } \\
\text { death; also expressed in postmitotic neurons for DNA repair }\end{array}$ & Schwartz et al., 2007; Bonda et al., 2009 \\
\hline PCNA & Cell proliferation & $\begin{array}{l}\text { May also be expressed during DNA repair and programmed } \\
\text { cell death or in nondividing cells }\end{array}$ & $\begin{array}{l}\text { Lin et al., 2001; Sanai et al., 2007; Bologna-Molina et al., } \\
2013\end{array}$ \\
\hline Nestin & Neural stem/progenitor cells & $\begin{array}{l}\text { Also expressed in mature glia and a subpopulation of mature } \\
\text { neurons and intermediate progenitors }\end{array}$ & $\begin{array}{l}\text { Doetsch et al., 1997; Farzanehfar et al., 2017; Krishnasamy et } \\
\text { al., } 2017\end{array}$ \\
\hline SOX2 & Neural progenitors & Also expressed in dividing glia and mature astrocytes & Komitova and Eriksson, 2004; Cruz et al., 2014 \\
\hline BLBP & Neural progenitors & Also expressed in astrocytes and many adult brain regions & Gerstner et al., 2008 \\
\hline TUJ1 & Immature neurons & $\begin{array}{l}\text { Expression may be retained in mature neurons, expressed in } \\
\text { mature basket cells in SGZ }\end{array}$ & Ambrogini et al., 2004; Seri et al., 2004 \\
\hline DCX & Immature neurons & $\begin{array}{l}\text { Expressed at low levels in oligodendrocytes and microglia, can } \\
\text { be reexpressed in mature neurons, also can indicate pro- } \\
\text { longed maturation instead new neuron generation }\end{array}$ & $\begin{array}{l}\text { Rotheneichner et al., 2018; Sorrells et al., 2018, 2019; Ohira et } \\
\text { al., } 2019\end{array}$ \\
\hline$C B$ & Mature neurons & Also a marker of a subtype of mature inhibitory interneurons & Tóth et al., 2010; Rocco et al., 2016 \\
\hline NeuN & Mature neurons & $\begin{array}{l}\text { Does not recognize all neuronal cell types, can be expressed in } \\
\text { subpopulations of oligodendrocytes and microglia }\end{array}$ & $\begin{array}{l}\text { Cannon and Greenamyre, 2009; Parakalan et al., 2012; Zhang } \\
\text { et al., } 2014\end{array}$ \\
\hline
\end{tabular}

makes new neurons destined for the olfactory bulb (Altman, 1969; Kaplan and Hinds, 1977; Lois and Alvarez-Buylla, 1994). Whether these processes continue in the adult human brain is of great interest but remains controversial. Although a few young neurons have been observed in the V-SVZ of the adult human brain (Wang et al., 2014; Sorrells et al., 2018), these cells are extremely rare, and generation of new neurons destined for the human olfactory bulb appears to continue after birth in infants, but it is rare, or nonoccurring, in the adult (Sanai et al., 2011). In the case of the adult human hippocampus, while some studies have suggested that neurogenesis in the human DG is a robust phenomenon with hundreds of new neurons being generated daily (Eriksson et al., 1998; Spalding et al., 2013; Boldrini et al., 2018), others find little evidence for progenitors or young neurons (Cipriani et al., 2018; Paredes et al., 2018; Sorrells et al., 2018). Based on observations of both proliferating and immature neuronal populations, we argue that hippocampal neurogenesis continues postnatally in humans, but decreases rapidly in children, and is rare or nonexistent in adults. The adult human brain lacks a proliferative zone or neurogenic niche in the DG, which is present in species where adult neurogenesis has been clearly documented. Most of the active proliferation that may be associated with neurogenesis is observed before 1 year of age. The developmental decline in proliferative and immature cells that is observed in childhood, originally intended to validate staining methods, strongly suggests that neurogenesis in the hippocampus diminishes before adolescence. Those arguing in favor of adult human hippocampal neurogenesis heavily rely on the immature neuron marker doublecortin (DCX). However, the presence of DCX is not sufficient evidence for newly formed neurons, as we and others (X. M. Zhang et al., 2009; Sorrells et al., 2019; R. X. Liu et al., 2020) have shown the presence of $\mathrm{DCX}^{+}$cells in non-neurogenic adult brain regions.

In this Dual Perspectives article, we present new evidence from young ages and from non-neurogenic brain regions showing that enhanced detection methods for DCX are not required to reveal $\mathrm{DCX}^{+}$neurons when they are present. Data obtained with enhanced detection may instead reveal low levels of marker expression in mature cells, reexpression in mature neurons, or cross-reactivity with related proteins. We discuss technical limitations associated with our methods and those used by others. Taking these limitations into account, this Dual Perspectives article considers our original findings in the context of new and conflicting datasets since 2019 and concludes that there is still reason to doubt the presence of neurogenesis in the adult human hippocampus. Our perspective remains that there are few to no new neurons being born in the adult human hippocampus.

\section{Defining adult neurogenesis}

Adult neurogenesis refers to the birth of a neuron in the adult brain. Recruitment of newly born neurons into a preexisting circuit involves additional steps, including migration, maturation, and synaptic integration. In the absence of direct lineage tracing methods to label dividing progenitors and follow their progeny, it is necessary to understand the developmental progression in multiple brain regions to be able to identify progenitors and immature neurons at different stages of maturation. Linking these two cellular populations is key to determining whether new neurons are being born in the adult brain.

Progenitor cells with proliferative potential are the foundation of neurogenesis. Dividing cells are best recognized when they undergo mitosis. However, these events are infrequent, so alternative labels for cells in the cell cycle are frequently used (e.g., Ki-67, MCM2). Co-stains with other molecular markers are required to determine the specific cell types that are dividing, and these labels are imperfect. Expression of PCNA, for example, has been interpreted as evidence of robust proliferation (Curtis et al., 2007). Yet it can be present in nondividing cells, including multiciliated ependymal cells that are postmitotic in adults (Sanai et al., 2007). Furthermore, PCNA is also expressed after DNA repair (Bologna-Molina et al., 2013). Alternative approaches have been used to infer the presence of newly generated cells, including BrdU immunolabeling or measuring ${ }^{14} \mathrm{C} \mathrm{lev-}$ els (Eriksson et al., 1998; Spalding et al., 2013). These studies are difficult to replicate and have several limitations, which we will discuss below (see also Sorrells et al., 2018, their Supplementary Discussion). 


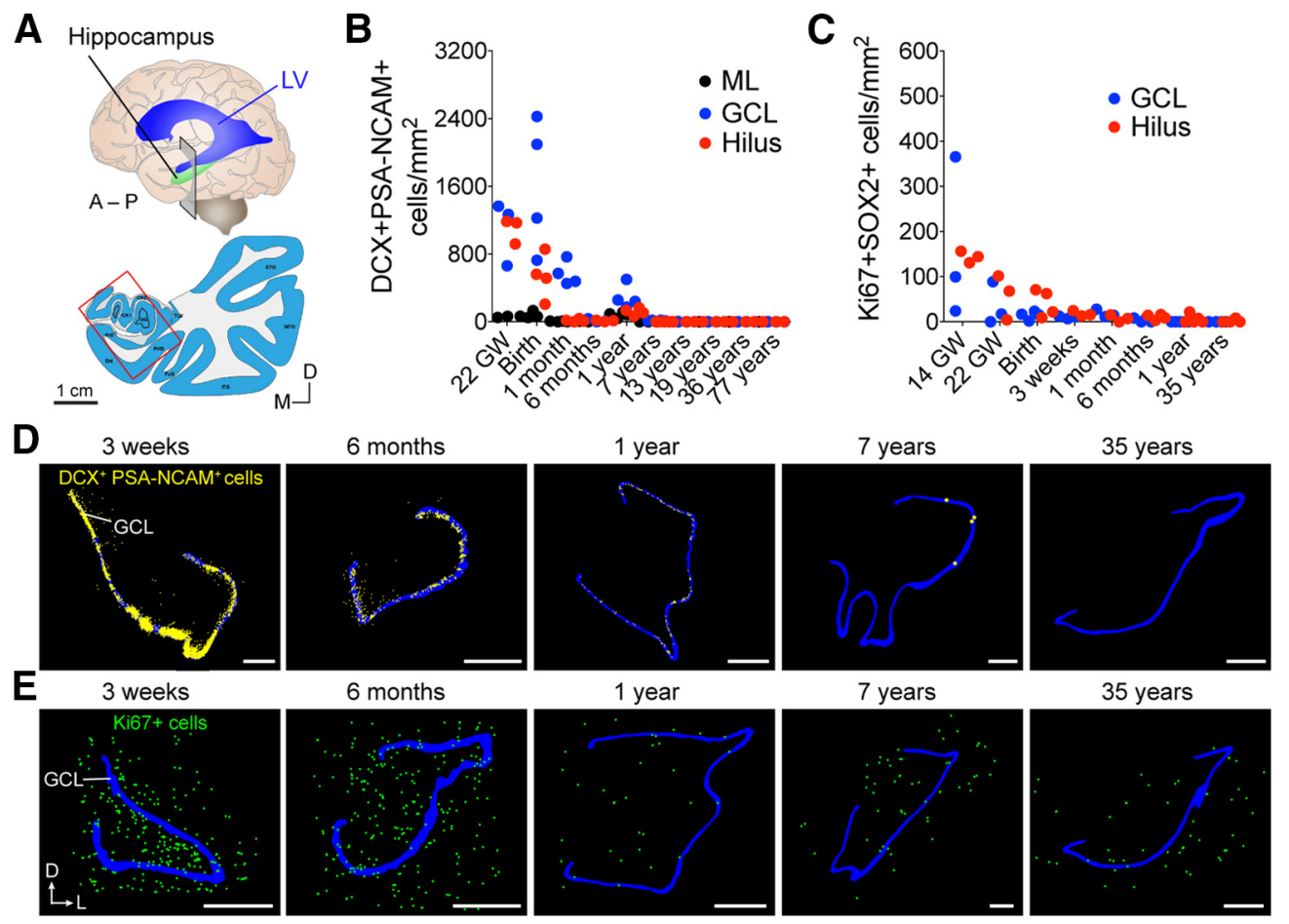

Figure 1. Early postnatal decline of dividing cells and immature neurons in the human hippocampus. $A$, Schematic of coronal section in the anterior hippocampus corresponding to maps in $D, E$. LV, Lateral ventricle; A, anterior; P, posterior; D, dorsal; L, lateral; M, medial. B, Quantification of DCX+ PSA-NCAM ${ }^{+}$cells in the human molecular layer (ML), GCL, and hilus between 22 gestational weeks (GW) and 77 years. C, Quantification of $\mathrm{Ki}_{-} 67^{+}$SOX2 ${ }^{+}$cells in the $\mathrm{GCL}$ and hilus between $14 \mathrm{GW}$ and 35 years. $\boldsymbol{D}$, Neurolucida maps of the location of DCX ${ }^{+}$PSA-NCAM ${ }^{+}$cells and $(\boldsymbol{E}) \mathrm{Ki}-67^{+}$cells (bottom) in the human hippocampus between 3 weeks and 35 years. $\boldsymbol{B}-\boldsymbol{E}$, Reproduced in part from Sorrells et al. (2018). Scale bars: $\boldsymbol{D}, \boldsymbol{E}, 1 \mathrm{~mm}$.

The presence of immature neurons is also frequently linked to ongoing neurogenesis. These cells have unique ultrastructural features, such as compacted heterochromatin, few organelles, small amounts of cytoplasm, and simple arborizations. However, as with dividing neural stem cells, experimental approaches for identifying immature neurons rely on molecular markers with limitations (Table 1). DCX, for example, is a cytoskeleton binding protein with multiple biological properties. There are many examples of $\mathrm{DCX}^{+}$immature neurons that are not newly generated in the adult mammalian brain, including in humans, macaques, cats, sheep, rats, and mice (X. M. Zhang et al., 2009; Gómez-Climent et al., 2011; Klempin et al., 2011; MartíMengual et al., 2013; Piumatti et al., 2018; Rotheneichner et al., 2018; Sorrells et al., 2019) where neurons may be maturing very slowly over the life of the animal (La Rosa et al., 2020b). While $\mathrm{DCX}^{+}$cells may be neurons newly recruited into adult neural circuits (Rotheneichner et al., 2018; Benedetti et al., 2020), they are not necessarily newly born.

Developmental decline of proliferation in the DG after birth When we analyzed the human DG at 14 gestational weeks, we observed the dentate neuroepithelium and dentate migratory stream next to the emerging granule cell layer (GCL). Intriguingly, the distribution of proliferating cells at 22 gestational weeks was asymmetric, suggesting that the human DG grows primarily from the blade proximal to the dentate neuroepithelium (Sorrells et al., 2018). Proliferation was already diminished across the entire DG by birth, with dividing cells present in the hilus and not specifically associated with the granule cell layer. In contrast, a germinal subgranular zone (SGZ) in other mammalian species, including nonhuman primates, is clearly identifiable as a cell dense region with many small cells containing compacted chromatin (Altman and Das, 1965).
During postnatal development, several studies have identified a clear drop in dividing cells and immature neurons during infancy in both the DG (Fig. 1) (Dennis et al., 2016; Cipriani et al., 2018; Sorrells et al., 2018) and subventricular zone (SVZ) (Sanai et al., 2011; Dennis et al., 2016). After 1 year of age, levels of Ki- $67^{+}$cells were equivalent across all regions of the hippocampus, and appeared comparable to the rest of the brain (Fig. $1 C, E)$ (Sorrells et al., 2018). This was also true for $\mathrm{Ki}-67^{+}$progenitor populations colabeled with SOX1, SOX2, BLBP, or vimentin, which were present in the infant hippocampus but greatly reduced by adolescence and rare in adults (Fig. 1C) (Sorrells et al., 2018). Data from other laboratories also converge on a low rate of proliferation in the adult human DG, similar to that in other regions of the hippocampus or the brain (Del Bigio, 1999; Knoth et al., 2010; Dennis et al., 2016; Cipriani et al., 2018; Seki et al., 2019).

The dramatic drop that occurs in proliferation during the first year of life is consistent with the disappearance of immature neurons that occurs during this time (Figs. 1-3). At young ages (birth to 22 months; Figs. $2 B, 3 B$ ), the $\mathrm{DCX}^{+} \mathrm{PSA}-\mathrm{NCAM}^{+}$immature neurons were located in close proximity to $\mathrm{Ki}-67^{+}$cells beneath the GCL, with most of their cell bodies on the hilar side. By birth and early postnatal stages, segments of the human GCL are already devoid of immature neurons; these areas increase in size with age (Fig. $2 C, D$ ). In regions lacking immature neurons, the GCL neurons were large, expressed NeuN, and had mature morphologic characteristics. Adding to this evidence, we show new examples at 22 months in Figures $2 B, D$ and $3 B$. These data fit with our originally reported observations at 1 and 7 years, indicating a sharp decline in dividing precursors and young neurons in infancy (Sorrells et al., 2018). Between 1 and 2 years, small clusters of immature neurons were still observed near Ki- $67^{+}$ cells (Figs. 2B, 3B), but these cells were rare at 7 and 13 years of 

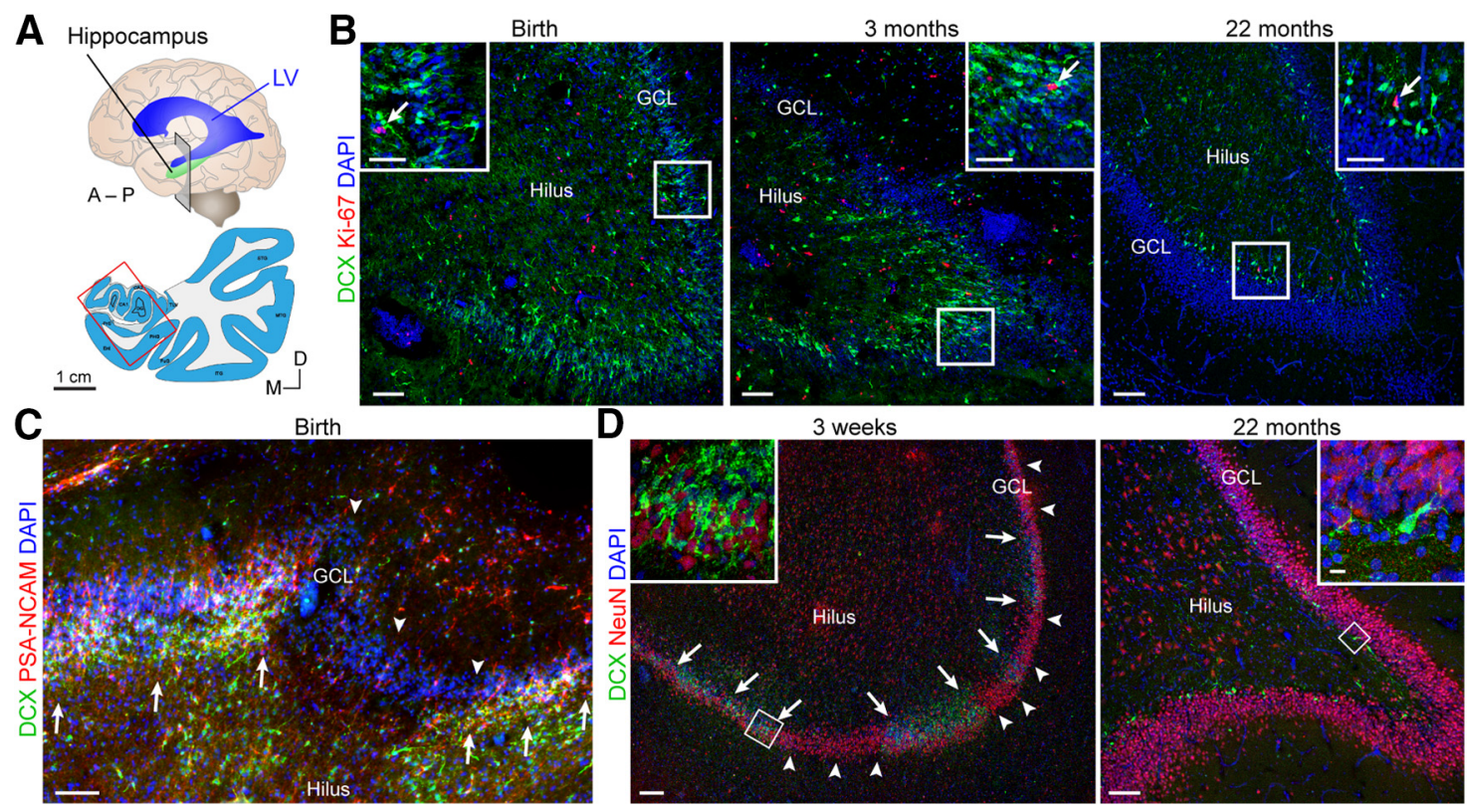

Figure 2. Cells with morphology and marker expression of young immature neurons are readily detected at young ages in humans. $A$, Schematic of coronal section in the anterior hippocampus corresponding to images in $\boldsymbol{B}-\boldsymbol{D} . \boldsymbol{B}, \mathbf{D C X}{ }^{+}$cells (green) and Ki-67 ${ }^{+}$cells (red) (insets, arrows) in the human $\mathrm{DG}$ at birth, 3 months, and 22 months. Although there is not a clear layer of proliferating cells forming a SGZ, there is a close correlation between proliferation and the presence of immature neurons. $C$, Already at birth, there are patches of the DG with (arrows) and without (arrowheads) DCX ${ }^{+}$PSA-NCAM ${ }^{+}$cells. $\boldsymbol{D}$, At 3 weeks, regions with many DCX ${ }^{+}$cells (arrows) are separated by large regions where $D C X^{+}$cells are absent (arrowheads). Scale bars: $\boldsymbol{B}-$ D, $100 \mu \mathrm{m} ; \boldsymbol{B}$, Insets, $50 \mu \mathrm{m} ; \boldsymbol{D}$, Insets, $10 \mu \mathrm{m}$.
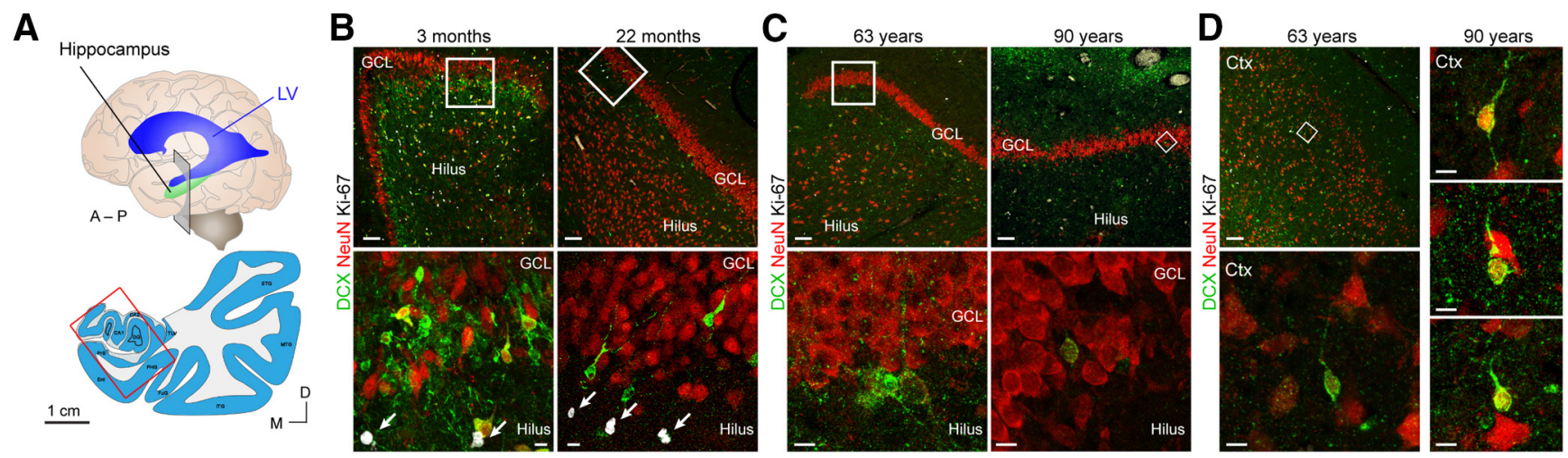

Figure 3. Dual antigen retrieval in young children reveals DG DCX ${ }^{+}$neurons with different morphology than those in the adult, as well as many neurons outside of the DG. $A$, Schematic of coronal section in the anterior hippocampus corresponding to images in $\boldsymbol{B}-\boldsymbol{D}$. $\boldsymbol{B}$, Between 3 and 22 months, small DCX ${ }^{+}$neurons (some also expressing NeuN) in the $\mathrm{GCL}$ are near $\mathrm{Ki}-67^{+}$cells (arrows). $C$, In adults 63 and 90 years of age, large $D C X^{+}$neurons expressing NeuN are not near Ki-67 ${ }^{+}$cells. $D$, In adults 63 and 90 years of age, many $D C X^{+}$cells expressing NeuN can be found in the cortex of the same sections as in C. Scale bars: $\boldsymbol{A}, 1 \mathrm{~cm} ; \boldsymbol{B}-\boldsymbol{D}$, Top, $100 \mu \mathrm{m} ; \boldsymbol{B}, \boldsymbol{C}$, Bottom, $\boldsymbol{D}$, Bottom, Right, $10 \mu \mathrm{m}$.

age (Fig. 4B) (Sorrells et al., 2018). If dividing progenitors were present but more dispersed compared with the consolidated layer seen in other species, young neurons with migratory morphology should be readily observed between the dividing cells and the more mature neurons. However, this is not the case in the human DG (Figs. 1D,E, 2B, 3B) and is consistent with work in the mouse SGZ showing that tangential dispersion of young neurons is limited (Sun et al., 2015).

\section{DCX labels more than just newborn neurons}

The field has often relied on the expression of DCX as a surrogate indicator for newly born neurons (Brown et al., 2003). DCX is a microtubule-associated protein that is essential for proper neuronal migration (Gleeson et al., 1999; Bai et al., 2003), and participates in cytoskeletal organization through interactions with and stabilization of microtubules and actin filaments
(Moores et al., 2006). Mutations in human DCX lead to cortical malformations, including lissencephaly, subcortical band heterotopias, and pachygyria, associated with poorly organized cortical layers and abnormal gyrification (Desikan and Barkovich, 2016). Its crucial role in neurodevelopment is undisputed.

Nevertheless, there are limitations to DCX serving as a unique or specific molecular marker for adult neurogenesis (Balthazart and Ball, 2014; Vellema et al., 2014; R. X. Liu et al., 2020). There is evidence that DCX expression can be long-lived in some cells. Human, nonhuman primate, and rodent data show that nonnewly born DCX-expressing cells can be observed in cortical regions, for example, the adult rodent piriform cortex or the human amygdala (X. M. Zhang et al., 2009; Gómez-Climent et al., 2011; Klempin et al., 2011; Martí-Mengual et al., 2013; Piumatti et al., 2018; Rotheneichner et al., 2018; Sorrells et al., 2019). The morphology of the $\mathrm{DCX}^{+}$cells at older ages is more 

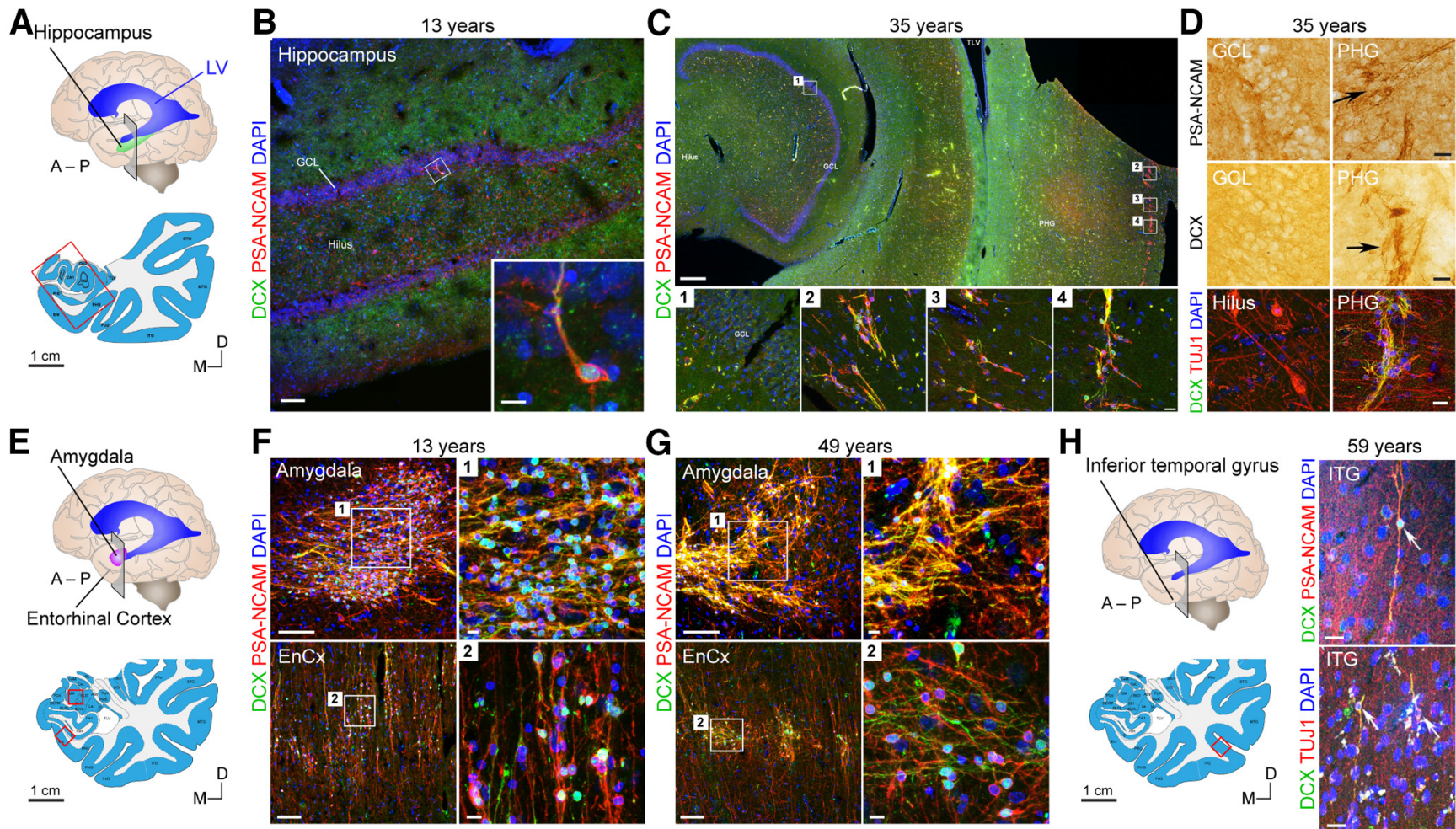

59 years

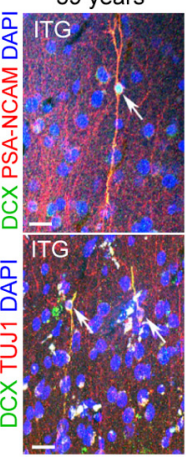

Figure 4. Immature $D C X^{+}$neurons are readily detectable in 4\% PFA-fixed material outside of the DG without dual antigen retrieval. $A$, Schematic of coronal section in the anterior hippocampus corresponding to images in $\boldsymbol{B}-\boldsymbol{D}$. $\boldsymbol{B}$, Low- and high-power images of one individual DCX+PSA-NCAM ${ }^{+}$neuron detected in the GCL in the same 13-year-old sample from Sorrells et al. (2018). C, In a 35-year-old adult, DCX ${ }^{+}$PSA-NCAM ${ }^{+}$cells are not detected in the DG (C1); but within the same section, cells are readily detected in the cortical parahippocampal gyrus (PHG) (C2-C4). D, Cells in the PHG stain for DCX, PSA-NCAM, and TUJ1, but similar cells are not present in the DG, and TUJ1 labels cells throughout the hilus. $\boldsymbol{E}$, Schematic of coronal section in the amygdala corresponding to images in $\boldsymbol{F}, \mathbf{G} . \boldsymbol{F}, \mathrm{DCX}^{+}$PSA-NCAM${ }^{+}$cells in the amygdala and entorhinal cortex (EnCX) in the same 13-year-old individual as in $\boldsymbol{B}$. $\boldsymbol{G}, \mathrm{DCX}^{+}$PSA-NCAM ${ }^{+}$cells in the amygdala and entorhinal cortex at 49 years of age. $\boldsymbol{H}$, Schematic and examples of DCX ${ }^{+}$PSA-NCAM ${ }^{+}$and DCX ${ }^{+} \mathrm{TUJ}^{+}$cells in the inferior temporal gyrus at 59 years of age. Scale bars: $A$, $\boldsymbol{E}, \boldsymbol{H}$, Left, $1 \mathrm{~cm} ; \boldsymbol{C}$, Top, $1 \mathrm{~mm} ; \boldsymbol{B}, \boldsymbol{F}$, Left, $\boldsymbol{G}$, Left, $100 \mu \mathrm{m} ; \boldsymbol{C}$, Insets, $\boldsymbol{D}, \boldsymbol{H}$, Right, $20 \mu \mathrm{m} ; \boldsymbol{B}$, Inset, $\boldsymbol{F}-\boldsymbol{H}$, Right, $10 \mu \mathrm{m}$

complex than that observed in development or within the mouse V-SVZ and SGZ. Mature neurons may also reexpress DCX. In the marmoset, for example, administration of the antidepressant fluoxetine increases the number of $\mathrm{DCX}^{+}$cells in the adult DG without increasing neurogenesis. These data suggest that mature GCL neurons may undergo "de-maturation" in which they begin to reexpress immature markers (Ohira et al., 2019). DCX ${ }^{+}$ expression might also indicate slow or delayed neuronal maturation, possibly associated with plasticity (see below).

PSA-NCAM is another marker that has been linked to newborn neurons. However, in well-preserved tissue without antigen retrieval, its expression is found in many regions of the adult CNS, including the hippocampus, and in many mature neurons (see Sorrells et al., 2018, their Extended Data Fig. $5 d$,e; see also Mathern et al., 2002; Varea et al., 2011). Expression of PSANCAM has been linked to areas with plasticity and remodeling: its expression is not necessarily associated with regions of neurogenesis (Theodosis et al., 1999). Thus, expression of DCX and/or PSA-NCAM might follow a timeline that is not necessarily associated with newly born cells in the adult.

In humans, newborn neurons may take many months to mature and might maintain immature markers, such as DCX and/or PSA-NCAM, for a long time. In support of this, studies performed in sheep (Lévy et al., 2017; Piumatti et al., 2018), marmoset (Sawamoto et al., 2011; Akter et al., 2020), and macaques (Kohler et al., 2011) show that there are species differences in the maturation rate of neurons. Neurons can take up to 3 months to mature in the marmoset, compared with 3-4 weeks for mouse neurons (Petreanu and Alvarez-Buylla, 2002; Carleton et al.,
2003; Zhao et al., 2006). The persistence of immature markers might be much more detectable than the presence of adult progenitor cells under these circumstances. A protracted maturation state of many months would translate into an increased number of $\mathrm{DCX}^{+} \mathrm{PSA}-\mathrm{NCAM}^{+}$cells; if neurogenesis continued robustly, we would expect to observe large numbers of $\mathrm{DCX}^{+} \mathrm{PSA}$ $\mathrm{NCAM}^{+}$cells in the dentate and neighboring hilus. Instead, DCX $^{+}$PSA-NCAM ${ }^{+}$cells are diminished already by 1 and 2 years of age, and only a handful of these cells are observed by 13 years (Fig. 4B) (Paredes et al., 2018; Sorrells et al., 2018).

Even if antibody best practices (Bordeaux et al., 2010) are followed, DCX antibodies can nonspecifically detect other markers (Buchwalow et al., 2011; R. X. Liu et al., 2020), and this problem may be potentiated by stringent antigen retrieval. In an effort to reproduce some of the observations from Llorens-Martín's laboratory (Moreno-Jiménez et al., 2019; Flor-García et al., 2020), we have used a similar double-antigen retrieval protocol and observed putative $\mathrm{DCX}^{+}$cells in DG in development and in adulthood (Fig. 3). However, the morphology and organization of $\mathrm{DCX}^{+}$cells we observe in children (Fig. $3 B$ ) are very different from those seen in the adult (Fig. $3 C$ ). Cells at the young ages are small with limited cytosol and few processes. Moreover, with double-antigen retrieval, we observe large, weakly labeled $\mathrm{DCX}^{+}$ cells with few processes in other non-neurogenic parts of the brain, including the cerebral cortex (Fig. 3D). Combined with the developmental trajectory, this suggests to us that the dual antigen retrieval in adult brains reveals neuronal populations that are not newly born. Whether this is detection of DCX protein, or cross reactivity with other proteins, remains to be 


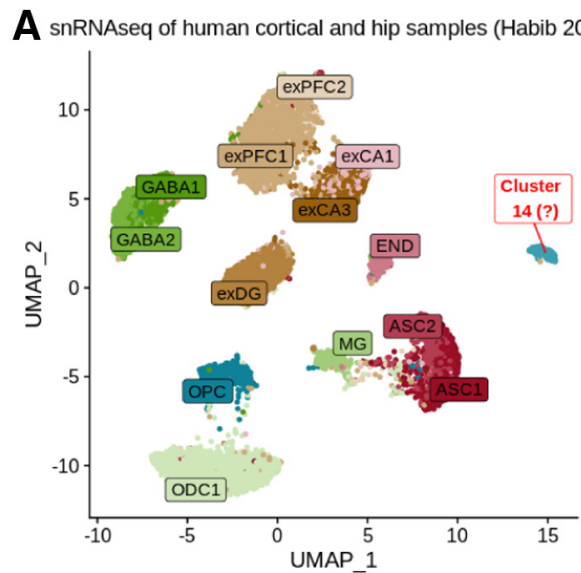

D DCX expression in human cortical and hip samples

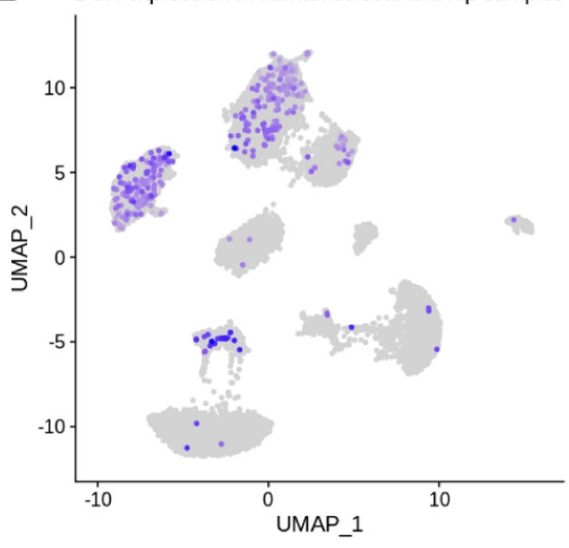

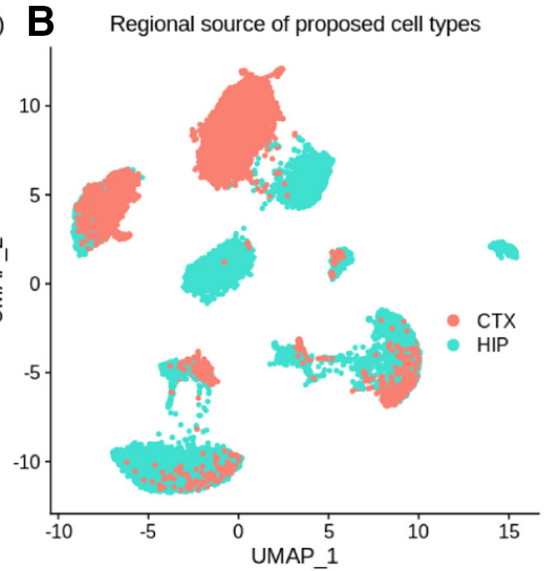

E

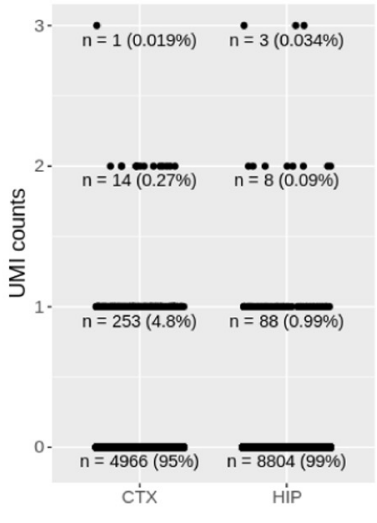

C Ependymal cell marker enrichment

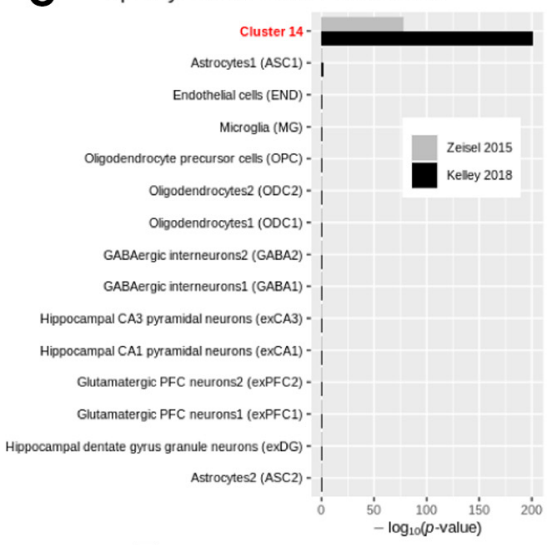

F

Bulk mRNA expression in human HIP

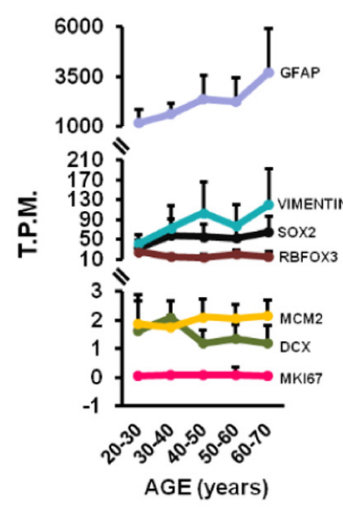

Figure 5. Lack of evidence of adult human hippocampal neural stem cells in both single nucleus and bulk RNA-seq data. A, UMAP plot of data from Habib et al. (2017), representing 14,137 nuclei from adult human PFC and hippocampus. UMI count matrix was obtained from the GTEx portal (https://www.gtexportal.org/home/datasets) and processed using default settings in Seurat (filtering for nuclei expressing a minimum of 200 genes and genes expressed in a minimum of 3 cells). Nuclei (dots) are labeled and colored by cluster membership labels from the original study: exPFC, Glutamatergic neurons from the PFC; GABA, GABAergic interneurons; exCA1/3, pyramidal neurons from the hip CA region; exDG, granule neurons from the hip DG region; ASC, astrocytes; MG, microglia; ODC, oligodendrocytes; OPC, oligodendrocyte precursor cells; SMC, smooth muscle cells; END, endothelial cells. Cluster 14 is equivalent to the cluster that Habib et al. (2017) identified and labeled as NSCs. $\boldsymbol{B}$, Region of origin of nuclei from $\boldsymbol{A}$. CTX, PFC; HIP, hippocampus. $\boldsymbol{C}$, Enrichment of ependymal cell type signatures in clusters from $\boldsymbol{A}$. Ependymal gene sets consist of 440 genes from either mouse (Zeisel et al., 2015) or human (Kelley et al., 2018) data. Enrichment analysis was performed using a one-sided Fisher's exact test using differentially expressed genes of all clusters shown in $\boldsymbol{A}$. Cluster 14, previously labeled as NSC, preferentially expresses ependymal genes. $\boldsymbol{D}$, Feature plot of DCX expression in all nuclei. $\boldsymbol{E}$, Quantification of UMI counts of DCX in all nuclei, grouped by region. Quantification of cell count per cluster, grouped by region. $\boldsymbol{F}$, Bulk mRNA expression (TPM) of genes related to astrocytes and RGCs (GFAP, vimentin, SOX2), neurons (RBFOX3, DCX), and cell proliferation (MCM2, MKI67) separated in different age groups (20-30 years; 30-40 years; 40-50 years; 50-60 years; 6070 years). The data used for the analysis were obtained from the GTEx Portal (GTEx Consortium, 2017). The donor eligibility requirements and sample collection process have been previously described (Carithers et al., 2015). We focused our analyses on the hippocampus, excluding the samples positive for Alzheimer disease ( $n=4)$ for a total 117 samples; $n=4$ in the 20 -30 age group; $n=3$ in the 30-40 age group; $n=13$ in the 40-50 age group; $n=32$ in the 50-60 age group; and $n=64$ in the $60-70$ age group. The data were normalized using 7 different housekeeping genes (PSMB4, GPI, RAB7A, VCP, C1orf43, CHMP2A, REEP5) previously described to be nonvariable in human tissue (Eisenberg and Levanon, 2013). The change along time is not significant in any of the genes, except for vimentin, which significantly increases from the 50-60 age range to the 60-70 age range ( $p=0.016)$. The statistical analysis was done by one-way ANOVA followed by all pairwise comparisons by Holm-Sidak post hoc test. Data are mean \pm SD.

determined (see below). There is evidence that DCX antibodies, including the one most frequently used by Llorens-Martín's laboratory (Santa Cruz Biotechnology, Goat sc-8066), have cross reactivity to other brain proteins (R. X. Liu et al., 2020). This may explain the staining, not only in the cortex, but also in the hippocampus. In our young samples, adult amygdala, or entorhinal cortex, there is no need to do double-antigen retrieval to detect clearly labeled cells (Figs. 2C,D, 4) (Paredes et al., 2018; Sorrells et al., 2018, 2019). Cross-adsorption controls are not sufficient to determine the specificity of the antibody (R. X. Liu et al., 2020).

Finally, DCX expression is not neuron-specific, which could explain why $\mathrm{DCX}^{+}$cells sometimes do not co-label with neuronal markers. DCX has been reported in oligodendrocyte precursors (Boulanger and Messier, 2017), microglia (J. Y. Liu et al., 2018; Sorrells et al., 2018; Unger et al., 2018), and in astrocyte subpopulations (Verwer et al., 2007). More recently, non-neuronal expression of DCX has been corroborated using single-cell sequencing (Franjic et al., 2021). Thus, $\mathrm{DCX}^{+}$cells that are not costained with specific neuron markers might be glial cells. These $\mathrm{DCX}^{+}$cells may divide and are often smaller, but with ramified morphologies that can be interpreted as immature neurons (and the absence of NeuN could be falsely interpreted as further reflection of an immature state).

\section{What is the nature of the $\mathrm{DCX}^{+}$cells in the adult human DG?}

Based on the above caveats, it is important to specifically consider the $\mathrm{DCX}^{+}$cells observed in the recent studies from Llorens-Martín in the DG (Moreno-Jiménez et al., 2019; FlorGarcía et al., 2020). Llorens-Martín argues that, for detection of DCX in the human DG, specific fixation and staining conditions 
are required. Using these conditions, many DCX-labeled cells are present in a single high-magnification confocal optical field taken from the human DG and the cells presented have mature morphology (e.g., Moreno-Jiménez et al., 2019, their Fig. 1J). If this region represented an area of continuous adult neurogenesis (the age of this sample is not specified), evidence of proliferation should also be observed. As discussed above, before 1 year of age, areas of DCX expression are associated with hilar proliferation and with cells at different stages of maturation (Figs. 1-3). In the adult samples shown by Llorens-Martín, the area under the dentate does not reveal a SGZ or levels of proliferation that would suggest ongoing neurogenesis, especially sufficient to explain the high number of $\mathrm{DCX}^{+}$cells detected. These observations raise the following questions about dual antigen retrieval staining: (1) Is the signal detected associated with DCX or with other epitopes, such as DCX-like domains in other proteins (Reiner et al., 2006; Dijkmans et al., 2010)? (2) Are unique fixation and staining conditions revealing low levels of DCX, possibly reexpressed in a subset of cells in old patients, as has been seen in the macaque DG (Hagihara et al., 2019)? (3) Are these low levels of DCX in cells that were produced earlier in adolescence or childhood? (4) Is this indeed evidence for large numbers of neurons produced in the elderly? One argument against this last interpretation, as discussed above, is the low number of proliferating cells in the DG and hilus reported across multiple studies.

Are we missing $\mathrm{DCX}^{+}$neurons in our adult samples because of sample processing, preservation, or quality? We argue this is not the case. As part of this Dual Perspectives article, we present data from a PFA-fixed brain with fixative perfusion $<5 \mathrm{~h}$ before fixation (Fig. 4C,D). Without using specialized antigen retrieval, there are clearly labeled $\mathrm{DCX}^{+}$cells that costained with PSANCAM in the parahippocampal gyrus, so it should be possible to detect similar cells in the DG within these same brains. But none were present.

To assess the morphologic and molecular identities of $\mathrm{DCX}^{+}$ cells that might represent new neurons in the adult human hippocampus, comparisons to known immature neurons are required. Sampling from younger tissue samples in development where immature $\mathrm{DCX}^{+}$young neurons are known to be present, or within other regions that have few immature $\mathrm{DCX}^{+}$cells, such as the ventricular wall, is an important benchmark. Recent studies (Moreno-Jiménez et al., 2019; Flor-García et al., 2020) claim that specialized sample preparation and staining protocols are required to identify $\mathrm{DCX}^{+}$immature neurons in the adult human brain, but they fail to detect $\mathrm{DCX}^{+}$cells in cortex where others have clearly documented their presence, and have not yet examined the V-SVZ. This raises questions about the effects of double-antigen retrieval and whether this method is unmasking unspecific immunostaining (R. X. Liu et al., 2020).

Finally, an argument to support the hypothesis that $\mathrm{DCX}^{+}$ cells in the adult human hippocampus are young neurons is that a subset of the $\mathrm{DCX}^{+}$cells costain with calretinin (CR) and not calbindin (CB). In birth-dated new neurons in the adult mouse hippocampus, these markers are turned on sequentially (Brandt et al., 2003). But the temporal expression pattern of CR and CB has not been validated in the human brain, and it is not clear that these different populations are part of the same lineage in the adult human brain. Indeed, many CR- and CB-positive cells are found outside the GCL, for example in the inner molecular layer. Additionally, CB and CR are expressed in adult interneurons in the hippocampus in both humans and mice (Gulyás et al., 1996; Tóth et al., 2010). Further validation of CR and CB labeling is needed to use these markers to test for adult neurogenesis and maturational state.
Different approaches to study adult neurogenesis in humans still give inconclusive evidence

A challenge to studying human neurogenesis is the lack of tools to directly and accurately birth-date or track newly born cells. Adult human DG neurogenesis was initially studied in a 5 patient cohort that received very low doses of BrdU (Eriksson et al., 1998). In this study, $\mathrm{BrdU}^{+}$cells were counted; however, these cells might have been non-neuronal. Several examples of BrdU costaining with $\mathrm{NeuN}, \mathrm{CB}$, and neuron-specific enolase were shown. But it is not known whether these are rare cases of new neurons, are because of BrdU incorporation independent of cell division in oncological/non-control patients, or are signals arising from technical issues associated with BrdU detection (Breunig et al., 2007). BrdU labeling requires harsh tissue treatments that can produce signals, even in the absence of BrdU or even primary or secondary antibodies in human tissue (see Sorrells et al., 2018 , their Extended Data Fig. 7f).

A study using ${ }^{14} \mathrm{C}$ birth-dating on sorted $\mathrm{NeuN}^{+}$nuclei suggested that hundreds of new neurons are generated per day in the adult human hippocampus, with little decline with age (Spalding et al., 2013). The results obtained from this method differ from histology studies that show a sharp decline in markers of newly formed neurons during early postnatal development (Knoth et al., 2010; Dennis et al., 2016; Sorrells et al., 2018). It should be noted that birth-dating with ${ }^{14} \mathrm{C}$ relies on the isolation of neuronal nuclei using NeuN antibodies, which are analyzed with mass spectrometry in bulk, not as single cells. With mathematical modeling of the population data, average birth dates are derived. Several technical aspects must be considered when interpreting ${ }^{14} \mathrm{C}$ results: Subpopulations of oligodendrocytes and microglia can also express NeuN (Parakalan et al., 2012; Y. Zhang et al., 2014), and these cells are known to divide in adults. In addition, ${ }^{14} \mathrm{C}$ can become incorporated into DNA through methylation or DNA repair, independent of cell division, and these processes have been shown to occur at high rates in the hippocampus (Münzel et al., 2010; Guo et al., 2011). Limitations of the ${ }^{14} \mathrm{C}$ analysis approach were seen when it was used for quantification of cellular regeneration in other tissues: the proposed addition of new neurons to the adult caudate nucleus (Ernst et al., 2014) is not supported by other work in humans or by BrdU labeling in adult macaques (Wang et al., 2014). ${ }^{14} \mathrm{C}$ data have yielded controversial results about heart muscle cell turnover: while ${ }^{14} \mathrm{C}$ data indicated that adult humans generate $\sim 0.5 \%-1 \%$ new heart muscle cells per year (Bergmann et al., 2009), no evidence for cell division was found with direct microscopy examination (Mollova et al., 2013), suggesting that ${ }^{14} \mathrm{C}$ levels might not be correlated with proliferation levels. In summary, these comparisons show that, although the ${ }^{14} \mathrm{C}$ method is innovative, the approach has not been validated in animal models to ensure accurate interpretation or reproduced in multiple laboratories.

New data regarding hippocampal progenitor cells and young neurons have started to emerge from single-nucleus and bulk RNA transcriptomics. The GTEx Project (GTEx Consortium, 2017) yielded 14,963 individual nuclei from adult human samples (hippocampus and PFC) that were transcriptomically profiled by Habib et al. (2017). They originally identified various clusters related to neuronal and glial cell types (Fig. 5A). Interestingly, one cluster (cluster 14 in the original study) consisted of 201 cells from hippocampus that were labeled by the authors as "neuronal stem cells" (NSCs) (Fig. 5B) based on the expression patterns of a handful of putative NSC marker genes. However, many of the top genes that define this cluster, 
including FOXJ1 and DNAH5, are functionally related to motile cilia, suggesting that this cluster may indeed represent ependymal cells. We performed a reanalysis of this dataset combined with an enrichment analysis of snRNAseq clusters with ependymal molecular markers previously identified in published mouse (Zeisel et al., 2015) or human (Kelley et al., 2018) sources. Our analyses revealed highly significant and specific enrichment of these gene sets in cluster 14 (Fig. $5 \mathrm{C}$ ). This reanalysis of these datasets indicates that the nuclei in this cluster correspond to ependymal cells and not NSCs. For this Dual Perspectives article, we also analyzed DCX expression in the same dataset and observed weak and scattered expression in nuclei corresponding to various cell types. Most $\mathrm{DCX}^{+}$cells corresponded to GABAergic neurons, oligodendrocyte precursor cells, and excitatory neurons from PFC, with hardly any $D C X$ expression detected in excitatory neurons from DG (Fig. 5D-F). Overall, only $5.12 \%$ of cortical cells (268 of 5234 ) and $1.11 \%$ of hippocampal cells (99 of 8903) had any DCX expression, which was detected at extremely low levels (1-3 UMIs; Fig. 5E). Another recent study performed snRNAseq of human hippocampus and found no evidence of a DCX-enriched cell population (Franjic et al., 2021). The authors did observe DCX-immunolabeled cells in the amygdala and entorhinal cortex, as we have (Sorrells et al., 2019); this might represent a reservoir of immature neurons (La Rosa et al., 2020a). The nature of these cells remains unknown, and they merit further evaluation.

Because technical variability and sampling bias can impact snRNAseq data (Kelley et al., 2018), for this Dual Perspectives article, we also analyzed bulk RNA expression data from 117 samples of adult human hippocampus from the GTEx Project and found that expression of DCX and proliferation genes (MKI67 and MCM2) was at noise levels (Fig. $5 F$ ). Yet another study of bulk RNA expression data in human hippocampus from prenatal to adult ages also found that expression of genes associated with neurogenesis, including DCX, declines rapidly after birth (Kumar et al., 2019). These data support the absence or limited presence of young neurons and dividing cells in adult human hippocampus, in line with our histologic analyses. Although transcription does not always correlate strongly with protein abundance (Greenbaum et al., 2003; Maier et al., 2009), these data are collectively consistent with our observations and suggest that, if neurogenesis continues in adult human DG, it is a rare phenomenon. Novel methods to label and study newborn cells or an approach to determine the ages of cells may help clarify the nature of $\mathrm{DCX}^{+}$cells in adult humans.

In conclusion, in the adult rodent brain, many new neurons continue to be generated in the V-SVZ of the lateral ventricle and the SGZ in the DG of the hippocampus. Whether similar processes occur in the adult human brain remains inconclusive and controversial. We argue that extensive antigen retrieval, or special immunocytochemical procedures (Moreno-Jiménez et al., 2019; Flor-García et al., 2020), are not needed to identify young neurons. With staining procedures that clearly reveal $\mathrm{DCX}^{+}$cells in amygdala, entorhinal, or parahippocampal cortex, we observe no evidence of young neurons in the DG. The double-antigen retrieval and immunocytochemical amplifications could reveal DCX-like proteins (Balthazart and Ball, 2014; Vellema et al., 2014; R. X. Liu et al., 2020); low levels of DCX known to be present in mature neurons (Ohira et al., 2019) or expression in non-neuronal cells (Verwer et al., 2007; Boulanger and Messier, 2017; J. Y. Liu et al., 2018; Sorrells et al., 2018; Unger et al., 2018; Franjic et al., 2021). Most neurons presented in Moreno-Jiménez et al. (2019) have a mature morphology and are located deep in the GCL, a location occupied by neurons that generated earlier developmental stages. There is also little evidence of progenitor cell proliferation within this region that would be expected for the reported density of $\mathrm{DCX}^{+}$cells. Together, our observations suggest that, in the adult human hippocampus, the addition of new neurons is rare or nonexistent.

We hope this discussion will stimulate new approaches to evaluate the production of new neurons in the human brain. Adult neurogenesis has been studied using lineage tracing, birthdating, and physiological measurements in only a small subset of mammalian species: macaque (Kornack and Rakic, 1999), sheep (Pérez-Martín et al., 2003; Brus et al., 2013), and rabbit (Luzzati et al., 2003); yet adult neurogenesis is thought to be a phenomenon that is widespread in mammals. Based on marker expression, there has been an effort to survey a variety of other mammalian species (Patzke et al., 2015). Even among the limited mammalian observations, high variability in the density of immature neurons and how it relates to a specific function have been reported. Adult mammals, such as dolphins and whales, with large complex brains that encounter complex memory and navigational challenges, do not appear to have new neurons in their hippocampi (Patzke et al., 2015; Parolisi et al., 2018). It is possible that species longevity or increased brain size constrains neurogenesis (Paredes et al., 2016; Charvet and Finlay, 2018; Snyder, 2019). It has also been previously speculated that longterm retention of memories might be incompatible with constant neuronal replacement (Rakic, 1985). An evolutionary and neuroethological perspective could provide important clues about the reasons for the decrease in this phenomenon along phylogenies (Nottebohm, 2002; Barnea and Pravosudov, 2011; Oppenheim, 2019).

Even if adult hippocampal neurogenesis in humans is rare, or nonexistent, studies of adult neurogenesis in rodents and in other species are extremely important: they provide basic information on how new neurons are made, the factors that regulate the division of neural stem cells and intermediate progenitors, and the way in which young neurons migrate and integrate within adult brain. These studies are fundamental to understand how young new neurons contribute to neural circuit function and plasticity and could help develop new approaches for neuronal replacement and repair.

\section{Response From Dual Perspective Companion} Author-María Llorens-Martín

It is not our intention to criticize the work of our colleagues. However, we consider that some statements made by Sorrells et al. are potentially misleading and should be clarified here:

Sorrells et al. claim that the application of a protocol similar to ours resulted in the appearance of unspecific DCX staining in their samples. Unfortunately, neither the protocol nor the tissue fixation/processing methodology they used is described in their Dual Perspectives article. We clearly demonstrated that $\mathrm{DCX}^{+}$cells are observed in human DG samples fixed for $<12 \mathrm{~h}$ in the absence of any pretreatment of the tissue (Moreno-Jiménez et al., 2019, Extended Data Fig. 2). Longer fixation of the samples obtained from the same individuals does require the application of particular pretreatments (see below) to 
reveal equivalent numbers of cells. These rigorous control experiments demonstrate that excessive fixation results in signal decay, a general phenomenon discovered six decades ago. We appreciate that the detailed description of our strictly controlled methodology has facilitated the reproducibility of our data (see Sorrells et al., their Fig. 3C).

Contrary to that stated by Sorrells et al., our optimized protocol is not based on dual antigen retrieval. Instead, it relies on mild antigen retrieval, incubation with $\mathrm{NaBH}_{4}$ (an aldehyde reducing agent), and autofluorescence elimination. The observation of $\mathrm{DCX}^{+}$cells in other brain regions reported here by Sorrells et al. may indeed be caused by excessive antigen retrieval (Flor-García, 2020, their Fig. 4). Importantly, we do not observe these cells with our carefully controlled protocol.

Our meticulous efforts to robustly demonstrate the presence of $\mathrm{DCX}^{+}$cells in the human DG included the use of five anti-DCX antibodies raised against different epitopes of the protein, all of which rendered similar results. Together with a tightly controlled preadsorption protocol, these data demonstrate the absence of cross-reactivity and validate signal specificity in the human DG. Similar exhaustive validation methods are crucial to prove the presence of $\mathrm{DCX}^{+}$cells in other regions of the human brain.

We acknowledge the putative value of state-of-the-art methodologies, such as single-cell RNAseq (scRNAseq), to study adult hippocampal neurogenesis. However, as Sorrells et al. affirm, these techniques still lack robust validation in this context. For instance, $>\mathbf{9 0} \%$ of the $\mathrm{DCX}^{+}$ cells reported by Moreno-Jiménez et al. (2019) are Prox $1^{+}$, which is exclusively expressed by dentate granule cells. In contrast, the RNAseq data reanalyzed by Sorrells et al. point to DCX mRNA expression in cells that do not express DCX protein (e.g., interneurons). This fact calls for caution when interpreting the latter results and questions their validity to refute the occurrence of human adult hippocampal neurogenesis.

Finally, Alvarez-Buylla questions the existence of a proliferative niche in the human DG. However, cell proliferation in this region has been reported by several studies, including ours (see Moreno-Jiménez et al., 2019, Fig. 2). Unfortunately, Sorrells et al. did not mention this evidence in their Dual Perspectives article. We fully agree with Alvarez-Buylla that deciphering the potentially unique features of the human hippocampal germinative zone is of capital importance and equally consider that addressing these differences merits in-depth studies, such as those currently being undertaken in our laboratory.

\section{References}

Flor-García M, Terreros-Roncal J, Moreno-Jiménez EP, Ávila J, Rábano A, Llorens-Martín M (2020) Unraveling human adult hippocampal neurogenesis. Nat Protoc 15:668-693.

Moreno-Jiménez EP, Flor-García M, Terreros-Roncal J, Rábano A, Cafini F, Pallas-Bazarra N, Ávila J, Llorens-Martín M (2019) Adult hippocampal neurogenesis is abundant in neurologically healthy subjects and drops sharply in patients with Alzheimer's disease. Nat Med 25:554-560.

\section{References}

Akter M, Kaneko N, Herranz-Pérez V, Nakamura S, Oishi H, GarcíaVerdugo JM, Sawamoto K (2020) Dynamic changes in the neurogenic potential in the ventricular-subventricular zone of common marmoset during postnatal brain development. Cereb Cortex 30:4092-4109.

Altman J (1969) Autoradiographic and histological studies of postnatal neurogenesis: IV. Cell proliferation and migration in the anterior forebrain, with special reference to persisting neurogenesis in the olfactory bulb. J Comp Neurol 137:433-457.

Altman J, Das GD (1965) Autoradiographic and histological evidence of postnatal hippocampal neurogenesis in rats. J Comp Neurol 124:319335.

Ambrogini P, Lattanzi D, Ciuffoli S, Agostini D, Bertini L, Stocchi V, Santi S, Cuppini R (2004) Morpho-functional characterization of neuronal cells at different stages of maturation in granule cell layer of adult rat dentate gyrus. Brain Res 1017:21-31.

Bai J, Ramos RL, Ackman JB, Thomas AM, Lee RV, LoTurco JJ (2003) RNAi reveals doublecortin is required for radial migration in rat neocortex. Nat Neurosci 6:1277-1283.

Balthazart J, Ball GF (2014) Doublecortin is a highly valuable endogenous marker of adult neurogenesis in canaries. Commentary on Vellema M, et al. (2014): Evaluating the predictive value of doublecortin as a marker for adult neurogenesis in canaries (Serinus canaria). J Comp Neurol 522:1299-1315.

Barnea A, Pravosudov V (2011) Birds as a model to study adult neurogenesis: bridging evolutionary, comparative and neuroethological approaches. Eur J Neurosci 34:884-907.

Benedetti B, Dannehl D, König R, Coviello S, Kreutzer C, Zaunmair P, Jakubecova D, Weiger TM, Aigner L, Nacher J, Engelhardt M, CouillardDesprés S (2020) Functional integration of neuronal precursors in the adult murine piriform cortex. Cereb Cortex 30:1499-1515.

Bergmann O, Bhardwaj RD, Bernard S, Zdunek S, Barnabé-Heider F, Walsh S, Zupicich J, Alkass K, Buchholz BA, Druid H, Jovinge S, Frisén J (2009) Evidence for cardiomyocyte renewal in humans. Science 324:98-102.

Boldrini M, Fulmore CA, Tartt AN, Simeon LR, Pavlova I, Poposka V, Rosoklija GB, Stankov A, Arango V, Dwork AJ, Hen R, Mann JJ (2018) Human hippocampal neurogenesis persists throughout aging. Cell Stem Cell 22:589-599.e5.

Bologna-Molina R, Mosqueda-Taylor A, Molina-Frechero N, Mori-Estevez AD, Sanchez-Acuna G (2013) Comparison of the value of PCNA and Ki67 as markers of cell proliferation in ameloblastic tumors. Med Oral Patol Oral Cir Bucal18:e174-e179.

Bonda DJ, Evans TA, Santocanale C, Llosá JC, Viña J, Bajic VP, Castellani RJ, Siedlak SL, Perry G, Smith MA, Lee HG (2009) Evidence for the progression through S-phase in the ectopic cell cycle re-entry of neurons in Alzheimer disease. Aging (Albany NY) 1:382-388.

Bordeaux J, Welsh AW, Agarwal S, Killiam E, Baquero MT, Hanna JA, Anagnostou VK, Rimm DL (2010) Antibody validation. BioTechniques 48:197-209.

Boulanger JJ, Messier C (2017) Doublecortin in oligodendrocyte precursor cells in the adult mouse brain. Front Neurosci 11:143.

Brandt MD, Jessberger S, Steiner B, Kronenberg G, Reuter K, Bick-Sander A, von der Behrens W, Kermpermann G (2003) Transient calretinin expression defines early postmitotic step of neuronal differentiation in adult hippocampal neurogenesis of mice. Mol Cell Neurosci 24:603-613.

Breunig JJ, Arellano JI, Macklis JD, Rakic P (2007) Everything that glitters isn't gold: a critical review of postnatal neural precursor analyses. Cell Stem Cell 1:612-627.

Brown JP, Couillard-Després S, Cooper-Kuhn CM, Winkler J, Aigner L, Kuhn HG (2003) Transient expression of doublecortin during adult neurogenesis. J Comp Neurol 467:1-10.

Brus M, Meurisse M, Gheusi G, Keller M, Lledo PM, Lévy F (2013) Dynamics of olfactory and hippocampal neurogenesis in adult sheep. J Comp Neurol 521:169-188.

Buchwalow I, Samoilova V, Boecker W, Tiemann M (2011) Non-specific binding of antibodies in immunohistochemistry: fallacies and facts. Sci Rep 1:28.

Cannon JR, Greenamyre TJ (2009) NeuN is not a reliable marker of dopamine neurons in rat substantia nigra. Neurosci Lett 464:14-17.

Carithers LJ, Ardlie K, Barcus M, Branton PA, Britton A, Buia SA, Compton CC, DeLuca DS, Peter-Demchok J, Gelfand ET, Guan P, Korzeniewski GE, Lockhart NC, Rabiner CA, Rao AK, Robinson KL, Roche NV, 
Sawyer SJ, Segré AV, Shive CE et al. (2015) A novel approach to highquality postmortem tissue procurement: The GTEx project. Biopreserv Biobank 13:311-319.

Carleton A, Petreanu LT, Lansford R, Alvarez-Buylla A, Lledo PM (2003) Becoming a new neuron in the adult olfactory bulb. Nat Neurosci 6:507518.

Charvet CJ, Finlay BL (2018) Comparing adult hippocampal neurogenesis across species: translating time to predict the tempo in humans. Front Neurosci 12:706.

Cipriani S, Ferrer I, Aronica E, Kovacs GG, Verney C, Nardelli J, Khung S, Delezoide AL, Milenkovic I, Rasika S, Manivet P, Benifla JL, Deriot N, Gressens P, Adle-Biassette H (2018) Hippocampal radial glial subtypes and their neurogenic potential in human fetuses and healthy and Alzheimer's disease adults. Cereb Cortex 28:2458-2478.

Cruz JD, La Cruz JO, Carrión-Navarro J, García-Romero N, GutiérrezMartín A, Lázaro-Ibáñez E, Escobedo-Lucea C, Perona R, Belda-Iniesta C, Ayuso-Sacido A (2014) SOX2 cell population from normal human brain white matter is able to generate mature oligodendrocytes. PLoS One 9:e99253.

Curtis MA, Kam M, Nannmark U, Anderson MF, Axell MZ, Wikkelso C, Holtås S, van Roon-Mom WM, Björk-Eriksson T, Nordborg C, Frisén J, Dragunow M, Faull RL, Eriksson PS (2007) Human neuroblasts migrate to the olfactory bulb via a lateral ventricular extension. Science 315:12431249.

Del Bigio MR (1999) Proliferative status of cells in adult human dentate gyrus. Microsc Res Tech 45:353-358.

Dennis CV, Suh LS, Rodriguez ML, Kril JJ, Sutherland GT (2016) Human adult neurogenesis across the ages: an immunohistochemical study. Neuropathol Appl Neurobiol 42:621-638.

Desikan RS, Barkovich AJ (2016) Malformations of cortical development. Ann Neurol 80:797-810.

Dijkmans TF, van Hooijdonk LW, Fitzsimons CP, Vreugdenhil E (2010) The doublecortin gene family and disorders of neuronal structure. Cent Nerv Syst Agents Med Chem 10:32-46.

Doetsch F, García-Verdugo JM, Alvarez-Buylla A (1997) Cellular composition and three-dimensional organization of the subventricular germinal zone in the adult mammalian brain. J Neurosci 17:5046-5061.

Eisenberg E, Levanon EY (2013) Human housekeeping genes, revisited. Trends Genet 29:569-574.

Eriksson PS, Perfilieva E, Björk-Eriksson T, Alborn AM, Nordborg C, Peterson DA, Gage FH (1998) Neurogenesis in the adult human hippocampus. Nat Med 4:1313-1317.

Ernst A, Alkass K, Bernard S, Salehpour M, Perl S, Tisdale J, Possnert G, Druid H, Frisén J (2014) Neurogenesis in the striatum of the adult human brain. Cell 156:1072-1083.

Farzanehfar P, Lu SS, Dey A, Musiienko D, Baagil H, Horne MK, Aumann TD (2017) Evidence of functional duplicity of Nestin expression in the adult mouse midbrain. Stem Cell Res 19:82-93.

Flor-García M, Terreros-Roncal J, Moreno-Jiménez EP, Ávila J, Rábano A, Llorens-Martín M (2020) Unraveling human adult hippocampal neurogenesis. Nat Protoc 15:668-693.

Franjic D, Choi J, Skarica M, Xu C, Li Q, Ma S, Tebbenkamp AT, Santpere G, Arellano JI, Gudelj I, Jankovic-Rapan L, Sousa AM, Rakic P, Sestan N (2021) Molecular diversity among adult human hippocampal and entorhinal cells. bioRxiv 889139. doi: 10.1101/2019.12.31.889139.

Gerstner JR, Bremer QZ, Vander Heyden WM, Lavaute TM, Yin JC, Landry CF (2008) Brain fatty acid binding protein (Fabp7) is diurnally regulated in astrocytes and hippocampal granule cell precursors in adult rodent brain. PLoS One 3:e1631.

Gleeson JG, Lin PT, Flanagan LA, Walsh CA (1999) Doublecortin is a microtubule-associated protein and is expressed widely by migrating neurons. Neuron 23:257-271.

Gómez-Climent MÁ, Hernández-González S, Shionoya K, Belles M, AlonsoLlosa G, Datiche F, Nacher J (2011) Olfactory bulbectomy, but not odor conditioned aversion, induces the differentiation of immature neurons in the adult rat piriform cortex. Neuroscience 181:18-27.

Greenbaum D, Colangelo C, Williams K, Gerstein M (2003) Comparing protein abundance and mRNA expression levels on a genomic scale. Genome Biol 4:117-118.

GTEx Consortium (2017) Genetic effects on gene expression across human tissues. Nature 550:204-213.
Gulyás AI, Hájos N, Freund TF (1996) Interneurons containing calretinin are specialized to control other interneurons in the rat hippocampus. J Neurosci 16:3397-3411.

Guo JU, Su Y, Zhong C, Ming GL, Song H (2011) Hydroxylation of 5-methylcytosine by TET1 promotes active DNA demethylation in the adult brain. Cell 145:423-434.

Habib N, Avraham-Davidi I, Basu A, Burks T, Shekhar K, Hofree M, Choudhury SR, Aguet F, Gelfand E, Ardlie K, Weitz DA, RozenblattRosen O, Zhang F, Regev A (2017) Massively parallel single-nucleus RNA-seq with DroNc-seq. Nat Methods 14:955-958.

Hagihara H, Murano T, Ohira K, Miwa M, Nakamura K, Miyakawa T (2019) Expression of progenitor cell/immature neuron markers does not present definitive evidence for adult neurogenesis. Mol Brain 12:108.

Kaplan MS, Hinds JW (1977) Neurogenesis in the adult rat: electron microscopic analysis of light radioautographs. Science 197:1092-1094.

Kelley KW, Nakao-Inoue H, Molofsky AV, Oldham MC (2018) Variation among intact tissue samples reveals the core transcriptional features of human CNS cell classes. Nat Neurosci 21:1171-1184.

Klempin F, Kronenberg G, Cheung G, Kettenmann H, Kempermann G (2011) Properties of doublecortin-(DCX)-expressing cells in the piriform cortex compared to the neurogenic dentate gyrus of adult mice. PLoS One 6:e25760.

Knoth R, Singec I, Ditter M, Pantazis G, Capetian P, Meyer RP, Horvat V, Volk B, Kempermann G (2010) Murine features of neurogenesis in the human hippocampus across the lifespan from 0 to 100 years. PLoS One 5:e8809.

Kohler SJ, Williams NI, Stanton GB, Cameron JL, Greenough WT (2011) Maturation time of new granule cells in the dentate gyrus of adult macaque monkeys exceeds six months. Proc Natl Acad Sci USA 108:1032610331.

Komitova M, Eriksson PS (2004) Sox-2 is expressed by neural progenitors and astroglia in the adult rat brain. Neurosci Lett 369:24-27.

Kornack DR, Rakic P (1999) Continuation of neurogenesis in the hippocampus of the adult macaque monkey. Proc Natl Acad Sci USA 96:57685773.

Krishnasamy S, Weng YC, Thammisetty SS, Phaneuf D, Lalancette-Hebert M, Kriz J (2017) Molecular imaging of nestin in neuroinflammatory conditions reveals marked signal induction in activated microglia. J Neuroinflammation 14:45.

Kumar A, Pareek V, Faiq MA, Kumar P, Kumari C, Singh HN, Ghosh SK (2019) Transcriptomic analysis of the neurogenesis signature suggests continued but minimal neurogenesis in the adult human hippocampus. bioRxiv 664995. doi: 10.1101/664995.

La Rosa C, Cavallo F, Pecora A, Chincarini M, Ala U, Faulkes CG, Nacher J, Cozzi B, Sherwood CC, Amrein I, Bonfanti L (2020a) Phylogenetic variation in cortical layer II immature neuron reservoir of mammals. Elife 9: e55456.

La Rosa C, Parolisi R, Bonfanti L (2020b) Brain structural plasticity: from adult neurogenesis to immature neurons. Front Neurosci 14:75.

Lévy F, Batailler M, Meurisse M, Migaud M (2017) Adult neurogenesis in sheep: characterization and contribution to reproduction and behavior. Front Neurosci 11:570.

Lin SH, Chong ZZ, Maiese K (2001) Cell cycle induction in post-mitotic neurons proceeds in concert with the initial phase of programmed cell death in rat. Neurosci Lett 310:173-177.

Liu JY, Matarin M, Reeves C, McEvoy AW, Miserocchi A, Thompson P, Sisodiya SM, Thom M (2018) Doublecortin-expressing cell types in temporal lobe epilepsy. Acta Neuropathol Commun 6:60.

Liu RX, Ma J, Wang B, Tian T, Guo N, Liu SJ (2020) No DCX-positive neurogenesis in the cerebral cortex of the adult primate. Neural Regen Res 15:1290-1299.

Lois C, Alvarez-Buylla A (1994) Long-distance neuronal migration in the adult mammalian brain. Science 264:1145-1148.

Luzzati F, Peretto P, Aimar P, Ponti G, Fasolo A, Bonfanti L (2003) Gliaindependent chains of neuroblasts through the subcortical parenchyma of the adult rabbit brain. Proc Natl Acad Sci USA 100:1303613041.

Maier T, Güell M, Serrano L (2009) Correlation of mRNA and protein in complex biological samples. FEBS Lett 583:3966-3973.

Martí-Mengual U, Varea E, Crespo C, Blasco-Ibáñez JM, Nacher J (2013) Cells expressing markers of immature neurons in the amygdala of adult humans. Eur J Neurosci 37:10-22. 
Mathern GW, Leiphart JL, De Vera A, Adelson PD, Seki T, Neder L, Leite JP (2002) Seizures decrease postnatal neurogenesis and granule cell development in the human fascia dentata. Epilepsia 43 Suppl 5:68-73.

Mollova M, Bersell K, Walsh S, Savla J, Das LT, Park SY, Silberstein LE, dos Remedios CG, Graham D, Colan S, Kühn B (2013) Cardiomyocyte proliferation contributes to heart growth in young humans. Proc Natl Acad Sci USA 110:1446-1451.

Moores CA, Perderiset M, Kappeler C, Kain S, Drummond D, Perkins SJ, Chelly J, Cross R, Houdusse A, Francis F (2006) Distinct roles of doublecortin modulating the microtubule cytoskeleton. EMBO J 25:4448-4457.

Moreno-Jiménez EP, Flor-García M, Terreros-Roncal J, Rábano A, Cafini F, Pallas-Bazarra N, Ávila J, Llorens-Martín M (2019) Adult hippocampal neurogenesis is abundant in neurologically healthy subjects and drops sharply in patients with Alzheimer's disease. Nat Med 25:554-560.

Munakata M, Watanabe M, Otsuki T, Itoh M, Uematsu M, Saito Y, Honda $\mathrm{R}$, Kure S (2013) Increased Ki-67 immunoreactivity in the white matter in hemimegalencephaly. Neurosci Lett 548:244-248.

Münzel M, Globisch D, Brückl T, Wagner M, Welzmiller V, Michalakis S, Müller M, Biel M, Carell T (2010) Quantification of the sixth DNA base hydroxymethylcytosine in the brain. Angew Chem Int Ed Engl 49:53755377.

Namba T, Mochizuki H, Onodera M, Mizuno Y, Namiki H, Seki T (2005) The fate of neural progenitor cells expressing astrocytic and radial glial markers in the postnatal rat dentate gyrus. Eur J Neurosci 22:1928-1941.

Nottebohm F (2002) Why are some neurons replaced in adult brain? J Neurosci 22:624-628.

Ohira K, Hagihara H, Miwa M, Nakamura K, Miyakawa T (2019) Fluoxetine-induced dematuration of hippocampal neurons and adult cortical neurogenesis in the common marmoset. Mol Brain 12:69.

Oppenheim RW (2019) Adult hippocampal neurogenesis in mammals (and humans): the death of a central dogma in neuroscience and its replacement by a new dogma. Dev Neurobiol 79:268-280.

Parakalan R, Jiang B, Nimmi B, Janani M, Jayapal M, Lu J, Tay SS, Ling EA, Dheen ST (2012) Transcriptome analysis of amoeboid and ramified microglia isolated from the corpus callosum of rat brain. BMC Neurosci 13:64.

Paredes MF, Sorrells SF, Garcia-Verdugo JM, Alvarez-Buylla A (2016) Brain size and limits to adult neurogenesis. J Comp Neurol 524:646664.

Paredes MF, Sorrells SF, Cebrian-Silla A, Sandoval K, Qi D, Kelley KW, James D, Mayer S, Chang J, Auguste KI, Chang EF, Gutierrez Martin AJ, Kriegstein AR, Mathern GW, Oldham MC, Huang EJ, Garcia-Verdugo JM, Yang Z, Alvarez-Buylla A (2018) Does adult neurogenesis persist in the human hippocampus? Cell Stem Cell 23:780-781.

Parolisi R, Cozzi B, Bonfanti L (2018) Humans and dolphins: Decline and fall of adult neurogenesis. Front Neurosci 12:497.

Patzke N, Spocter MA, Karlsson KÆ, Bertelsen MF, Haagensen M, Chawana R, Streicher S, Kaswera C, Gilissen E, Alagaili AN, Mohammed OB, Reep RL, Bennett NC, Siegel JM, Ihunwo AO, Manger PR (2015) In contrast to many other mammals, cetaceans have relatively small hippocampi that appear to lack adult neurogenesis. Brain Struct Funct 220:361-383.

Pérez-Martín M, Cifuentes M, Grondona JM, Bermúdez-Silva FJ, Arrabal PM, Pérez-Fígares JM, Jiménez AJ, García-Segura LM, Férnandez-Llebrez P (2003) Neurogenesis in explants from the walls of the lateral ventricle of adult bovine brain: role of endogenous IGF1 as a survival factor. Eur J Neurosci 17:205-211.

Petreanu L, Alvarez-Buylla A (2002) Maturation and death of adult-born olfactory bulb granule neurons: role of olfaction. J Neurosci 22:6106-6113.

Piumatti M, Palazzo O, La Rosa C, Crociara P, Parolisi R, Luzzati F, Lévy F, Bonfanti L (2018) Non-newly generated, "immature" neurons in the sheep brain are not restricted to cerebral cortex. J Neurosci $38: 826-842$

Rakic P (1985) Limits of neurogenesis in primates. Science 227:1054-1056.

Reiner O, Coquelle FM, Peter B, Levy T, Kaplan A, Sapir T, Orr I, Barkai N, Eichele G, Bergmann S (2006) The evolving doublecortin (DCX) superfamily. BMC Genomics 7:188.
Rocco BR, Sweet RA, Lewis DA, Fish KN (2016) GABA-synthesizing enzymes in calbindin and calretinin neurons in monkey prefrontal cortex. Cereb Cortex 26:2191-2204.

Rotheneichner P, Belles M, Benedetti B, König R, Dannehl D, Kreutzer C, Zaunmair P, Engelhardt M, Aigner L, Nacher J, Couillard-Despres S (2018) Cellular plasticity in the adult murine piriform cortex: continuous maturation of dormant precursors into excitatory neurons. Cereb Cortex 28:2610-2621.

Sanai N, Berger MS, Garcia-Verdugo JM, Alvarez-Buylla A (2007) Comment on "Human neuroblasts migrate to the olfactory bulb via a lateral ventricular extension." Science 318:393; author reply 393.

Sanai N, Nguyen T, Ihrie RA, Mirzadeh Z, Tsai HH, Wong M, Gupta N, Berger MS, Huang E, Garcia-Verdugo JM, Rowitch DH, Alvarez-Buylla A (2011) Corridors of migrating neurons in the human brain and their decline during infancy. Nature 478:382-386.

Sawamoto K, Hirota Y, Alfaro-Cervello C, Soriano-Navarro M, He X, Hayakawa-Yano $Y$, Yamada $M$, Hikishima $K$, Tabata $H$, Iwanami A, Nakajima K, Toyama Y, Itoh T, Alvarez-Buylla A, Garcia-Verdugo JM, Okano H (2011) Cellular composition and organization of the subventricular zone and rostral migratory stream in the adult and neonatal common marmoset brain. J Comp Neurol 519:690-713

Schnitzer J, Franke WW, Schachner M (1981) Immunocytochemical demonstration of vimentin in astrocytes and ependymal cells of developing and adult mouse nervous system. J Cell Biol 90:435-447.

Schwartz EI, Smilenov LB, Price MA, Osredkar T, Baker RA, Ghosh S, Shi FD, Vollmer TL, Lencinas A, Stearns DM, Gorospe M, Kruman II (2007) Cell cycle activation in postmitotic neurons is essential for DNA repair. Cell Cycle 6:318-329.

Seki T, Hori T, Miyata H, Maehara M, Namba T (2019) Analysis of proliferating neuronal progenitors and immature neurons in the human hippocampus surgically removed from control and epileptic patients. Sci Rep 9:18194.

Seri B, García-Verdugo JM, McEwen BS, Alvarez-Buylla A (2001) Astrocytes give rise to new neurons in the adult mammalian hippocampus. J Neurosci 21:7153-7160

Seri B, García-Verdugo JM, Collado-Morente L, McEwen BS, Alvarez-Buylla A (2004) Cell types, lineage, and architecture of the germinal zone in the adult dentate gyrus. J Comp Neurol 478:359-378.

Snyder JS (2019) Recalibrating the relevance of adult neurogenesis. Trends Neurosci 42:164-178.

Sorrells SF, Paredes MF, Cebrian-Silla A, Sandoval K, Qi D, Kelley KW, James D, Mayer S, Chang J, Auguste KI, Chang EF, Gutierrez AJ, Kriegstein AR, Mathern GW, Oldham MC, Huang EJ, Garcia-Verdugo JM, Yang Z, Alvarez-Buylla A (2018) Human hippocampal neurogenesis drops sharply in children to undetectable levels in adults. Nature 555:377-381.

Sorrells SF, Paredes MF, Velmeshev D, Herranz-Pérez V, Sandoval K, Mayer S, Chang EF, Insausti R, Kriegstein AR, Rubenstein JL, Garcia-Verdugo JM, Huang EJ, Alvarez-Buylla A (2019) Immature excitatory neurons develop during adolescence in the human amygdala. Nat Commun 10:2748.

Souza DG, Bellaver B, Terra SR, Guma FC, Souza DO, Quincozes-Santos A (2017) In vitro adult astrocytes are derived from mature cells and reproduce in vivo redox profile. J Cell Biochem 118:3111-3118.

Spalding KL, Bergmann O, Alkass K, Bernard S, Salehpour M, Huttner HB, Boström E, Westerlund I, Vial C, Buchholz BA, Possnert G, Mash DC, Druid H, Frisén J (2013) Dynamics of hippocampal neurogenesis in adult humans. Cell 153:1219-1227.

Sun GJ, Zhou Y, Stadel RP, Moss J, Yong JH, Ito S, Kawasaki NK, Phan AT, Oh JH, Modak N, Reed RR, Toni N, Song H, Ming GL (2015) Tangential migration of neuronal precursors of glutamatergic neurons in the adult mammalian brain. Proc Natl Acad Sci USA 112:9484-9489.

Theodosis DT, Bonhomme R, Vitiello S, Rougon G, Poulain DA (1999) Cell surface expression of polysialic acid on NCAM is a prerequisite for activity-dependent morphological neuronal and glial plasticity. J Neurosci 19:10228-10236.

Tóth K, Eross L, Vajda J, Halász P, Freund TF, Maglóczky Z (2010) Loss and reorganization of calretinin-containing interneurons in the epileptic human hippocampus. Brain 133:2763-2777.

Unger MS, Marschallinger J, Kaindl J, Klein B, Johnson M, Khundakar AA, Roßner S, Heneka MT, Couillard-Despres S, Rockenstein E, Masliah E, Attems J, Aigner L (2018) Doublecortin expression in CD8 T-cells and 
microglia at sites of amyloid- $\beta$ plaques: a potential role in shaping plaque pathology? Alzheimers Dement 14:1022-1037.

van Praag H, Schinder AF, Christie BR, Toni N, Palmer TD, Gage FH (2002) Functional neurogenesis in the adult hippocampus. Nature 415:1030-1034.

Varea E, Belles M, Vidueira S, Blasco-Ibáñez JM, Crespo C, Pastor AM, Nacher J (2011) PSA-NCAM is expressed in immature, but not recently generated, neurons in the adult cat cerebral cortex layer II. Front Neurosci 5:17.

Varea E, Castillo-Gómez E, Gómez-Climent MA, Blasco-Ibáñez JM, Crespo C, Martínez-Guijarro FJ, Nàcher J (2007) PSA-NCAM expression in the human prefrontal cortex. J Chem Neuroanat 33:202-209.

Vellema M, Hertel M, Urbanus SL, Van der Linden A, Gahr M (2014) Evaluating the predictive value of doublecortin as a marker for adult neurogenesis in canaries (Serinus canaria). J Comp Neurol 522:1299-1315.

Verwer RW, Sluiter AA, Balesar RA, Baayen JC, Noske DP, Dirven CM, Wouda J, van Dam AM, Lucassen PJ, Swaab DF (2007) Mature astrocytes in the adult human neocortex express the early neuronal marker doublecortin. Brain 130:3321-3335.

Wang C, You Y, Qi D, Zhou X, Wang L, Wei S, Zhang Z, Huang W, Liu Z, Liu F, Ma L, Yang Z (2014) Human and monkey striatal interneurons are derived from the medial ganglionic eminence but not from the adult subventricular zone. J Neurosci 34:1090610923.

Zeisel A, Muñoz-Manchado AB, Codeluppi S, Lönnerberg P, La Manno G, Juréus A, Marques S, Munguba H, He L, Betsholtz C, Rolny C, CasteloBranco G, Hjerling-Leffler J, Linnarsson S (2015) Brain structure: cell types in the mouse cortex and hippocampus revealed by single-cell RNA-seq. Science 347:1138-1142.

Zhang XM, Cai Y, Chu Y, Chen EY, Feng JC, Luo XG, Xiong K, Struble RG, Clough RW, Patrylo PR, Kordower JH, Yan XX (2009) Doublecortin-expressing cells persist in the associative cerebral cortex and amygdala in aged nonhuman primates. Front Neuroanat 3:17.

Zhang Y, Chen K, Sloan SA, Bennett ML, Scholze AR, O'Keeffe S, Phatnani HP, Guarnieri P, Caneda C, Ruderisch N, Deng S, Liddelow SA, Zhang C, Daneman R, Maniatis T, Barres BA, Wu JQ (2014) An RNA-sequencing transcriptome and splicing database of glia, neurons, and vascular cells of the cerebral cortex. J Neurosci 34:11929-11947.

Zhao C, Teng EM, Summers RG Jr, Ming GL, Gage FH (2006) Distinct morphological stages of dentate granule neuron maturation in the adult mouse hippocampus. J Neurosci 26:3-11. 